\title{
Mycoplasma adleri sp. nov., an Isolate from a Goat
}

\author{
RICHARD A. DEL GIUDICE, ${ }^{1 *}$ DAVID L. ROSE, ${ }^{\dagger} \dagger$ AND JOSEPH G. TULLY ${ }^{2}$ \\ Mycoplasma Laboratory, PRI/DynCorp, Frederick Cancer Research and Development Center, National Cancer \\ Institute, Frederick, Maryland 21702, ${ }^{1}$ and Mycoplasma Section, Laboratory of Molecular Microbiology, \\ National Institute of Allergy and Infectious Diseases, Frederick, Maryland $21702^{2}$
}

\begin{abstract}
Mycoplasma sp. strain $\mathrm{G145}^{\mathrm{T}}$ (T $=$ type strain) was isolated from a goat's abscessed ankle. Strain G145 $^{\mathrm{T}}$ required cholesterol or serum for growth and possessed characteristics similar to those of other members of the genus Mycoplasma. This strain was serologically distinct from previously described Mycoplasma species and from a group of currently unnamed strains thought to belong to the genus Mycoplasma. Strain G145 $^{\mathrm{T}}$ hydrolyzed arginine, but did not hydrolyze urea or ferment glucose. The guanine-plus-cytosine content of the DNA was $29.6 \mathrm{~mol} \%$. We propose that strain G145 (= ATCC 27948) is the type strain of a new species, for which we propose the name Mycoplasma adleri.
\end{abstract}

Mycoplasma strain $\mathrm{G} 145^{\mathrm{T}}$ ( $\mathrm{T}=$ type strain) was isolated from a goat's open ankle joint abscess during a suppurative arthritis outbreak in a Maryland goat herd in 1967. In preliminary studies, strain $\mathrm{G} 145^{\mathrm{T}}$ was characterized as a new Mycoplasma species, and it was found to be serologically distinct from the previously recognized species in the genus. We distributed cultures of this strain to other investigators, and it was subsequently included in various comparative studies of caprine mycoplasmas $(2,6-8,10)$, in which it was also found to be unrelated to previously described Mycoplasma species. Additional serologic comparisons of strain $\mathrm{G} 145^{\mathrm{T}}$ with other newly isolated mycoplasmas have occurred over the intervening 27 years without any suggestion that this organism is related to any other established species.

In this paper we designate strain G145 the type strain of a new Mycoplasma species, describe additional characteristics of strain G145, and summarize the serologic relationship between this organism and previously described species belonging to the genus Mycoplasma.

\section{MATERIALS AND METHODS}

Mycoplasmas, culture medium, and cultivation techniques. Strain $\mathrm{G} 145^{\mathrm{T}}$ was isolated on Edward medium (12), a formulation consisting of heart infusion broth, fresh yeast extract, and $20 \%$ horse serum. For solid growth medium, $0.8 \%$ (wt/vol) agarose was added to Edward medium; the inoculated media were incubated at $35^{\circ} \mathrm{C}$ under an anaerobic atmosphere (GasPak system; BBL Microbiology Systems, Cockeysville, Md.). The strain was purified by filtration cloning (18). Early-passage cultures were grown on liquid medium withou penicillin or other antibiotics for at least five consecutive passages; each subculture was plated onto blood agar and incubated at $35^{\circ} \mathrm{C}$. After 2 to 4 days the plates were examined for bacterial colonies.

Morphological studies. Liquid cultures were examined by dark-field microscopy. Cellular morphology was also assessed after Gram staining and observation by light microscopy. The ultrastructure of the cells was also determined by electron microscopy, as described previously (5).

Filtration studies. The filterability of strain $\mathrm{G} 145^{\mathrm{T}}$ was assessed by using $24-$ to 48-h-old liquid cultures (18). A series of cellulose acetate membrane filters (Millipore Corp., Bedford, Mass.) with average pore sizes rated at $800,450,300$, and $220 \mathrm{~nm}$ were used. Serial 10-fold dilutions of filtrates and control liquid cultures were inoculated onto agar medium, and the resulting preparations were incubated at $35^{\circ} \mathrm{C}$ to determine the viable titers of the filtrates, which were expressed as CFU per milliliter.

Tests for biological and biochemical properties. The procedures used to determine glucose fermentation, arginine hydrolysis, urea hydrolysis, phosphatase activity, tetrazolium reduction, serum liquefaction, and the film and spot reaction have been described previously $(1,3)$. Hemadsorption of guinea pig

${ }^{*}$ Corresponding author. Mailing address: PRI/DynCorp, NCIFCRDC, P.O. Box B, Frederick, MD 21702. Phone: (301) 846-1385.

$\dagger$ Present address: 8602 Cinnamon Creek, San Antonio, TX 78284. erythrocytes to colonies of strain $\mathrm{G} 145^{\mathrm{T}}$ was also assessed by a technique described previously (13).

Sterol requirement. The sterol growth requirement of strain $\mathrm{G} 145^{\mathrm{T}}$ was determined by a standard liquid culture technique $(17,19)$

Serologic tests. We prepared hyperimmune rabbit antisera and fluorescein conjugates to Mycoplasma species and to a collection of unclassified strains by using conventional techniques that have been described previously (20). All sera and conjugates were maintained in the Mycoplasma Section of the National Institute of Allergy and Infectious Diseases. Some equine and caprine antisera and fluorescent antibody conjugates were prepared as part of the Reference Reagent Program of the National Institute of Allergy and Infectious Diseases (9). Antisera and conjugates of the following mycoplasmas were used in serologic tests: Mycoplasma agalactiae $\mathrm{PG} 2^{\mathrm{T}}, M$. alkalescens $\mathrm{D} 12^{\mathrm{T}}, M$. alvi $\mathrm{Ilsley}^{\mathrm{T}}, M$. anatis $1340^{\mathrm{T}}, M$. anseris $1219^{\mathrm{T}}, M$. arginini $\mathrm{G} 230^{\mathrm{T}}, M$. arthritidis $\mathrm{PG}{ }^{\mathrm{T}}, M$. auris $\mathrm{U}^{\mathrm{A}} \mathrm{A}^{\mathrm{T}}$, $M$. bovigenitalium $\mathrm{PG}^{\mathrm{T}}{ }^{\mathrm{T}}, M$. bovirhinis $\mathrm{PG} 43^{\mathrm{T}}, M$. bovis Donetta ${ }^{\mathrm{T}}, M$. bovoculi $\mathrm{M} 165 / 69^{\mathrm{T}}, M$. buccale $\mathrm{CH} 20247^{\mathrm{T}}, M$. buteonis $\mathrm{Bb} / \mathrm{T}^{2} \mathrm{~g}^{\mathrm{T}}, M$. californicum $\mathrm{ST}-6^{\mathrm{T}}$, $M$. canadense $275 \mathrm{C}^{\mathrm{T}}, M$. canis $\mathrm{PG} 14^{\mathrm{T}}, M$. capricolum subsp. capricolum California $\mathrm{Kid}^{\mathrm{T}}, M$. capricolum subsp. capripneumoniae $\mathrm{F} 38^{\mathrm{T}}, M$. caviae $\mathrm{G} 122^{\mathrm{T}}, M$. cavipharyngis $117 \mathrm{C}^{\mathrm{T}}, M$. citelli $\mathrm{RG}-2 \mathrm{C}^{\mathrm{T}}, M$. cloacale $383^{\mathrm{T}}, M$. collis $58 \mathrm{~B}^{\mathrm{T}}, M$ columbinasale $694^{\mathrm{T}}, M$. columbinum $\mathrm{MMP}-1^{\mathrm{T}}, M$. columborale $\mathrm{MMP}-4^{\mathrm{T}}, M$ conjunctivae $\mathrm{HRC} 81^{\mathrm{T}}, M$. corogypsi $\mathrm{BV}^{\mathrm{T}}, M$. cottewii $\mathrm{VIS}^{\mathrm{T}}, M$. cricetuli $\mathrm{CH}^{\mathrm{T}}$, $M$. cynos $\mathrm{H} 831^{\mathrm{T}}, M$. dispar $462 / 2^{\mathrm{T}}, M$. edwardii $\mathrm{PG} 24^{\mathrm{T}}, M$. equigenitalium $\mathrm{T} 37^{\mathrm{T}}$, M. equirhinis $\mathrm{M} 432 / 72^{\mathrm{T}}, M$. falconis $\mathrm{H} / \mathrm{T} 1^{\mathrm{T}}, M$. fastidiosum $4822^{\mathrm{T}}, M$. faucium DC333 ${ }^{\mathrm{T}}, M$. felifaucium $\mathrm{PV}^{\mathrm{T}}, M$. feliminutum $\mathrm{Ben}^{\mathrm{T}}, M$. felis $\mathrm{CO}^{\mathrm{T}}, M$. fermentans $\mathrm{PG}^{\mathrm{T}}{ }^{\mathrm{T}}, M$. flocculare $\mathrm{Ms} 42^{\mathrm{T}}, M$. gallinaceum $\mathrm{DD}^{\mathrm{T}}, M$. gallinarum $\mathrm{PG} 16^{\mathrm{T}}, M$. gallisepticum $\mathrm{PG} 31^{\mathrm{T}}, M$. gallopavonis $\mathrm{WR} 1^{\mathrm{T}}, M$. gateae $\mathrm{CS}^{\mathrm{T}}, M$. genitalium $\mathrm{G} 37^{\mathrm{T}}$, $M$. glycophilum $486^{\mathrm{T}}, M$. gypis $\mathrm{B} 1 / \mathrm{T} 1, M$. hominis $\mathrm{PG} 21^{\mathrm{T}}, M$. hyophanngis $\mathrm{H} 3-6 \mathrm{BF}^{\mathrm{T}}, M$. hyopneumoniae $\mathrm{J}^{\mathrm{T}}, M$. hyorhinis $\mathrm{BTS}^{\mathrm{T}}, M$. hyosynoviae $\mathrm{S}^{\mathrm{T}}{ }^{\mathrm{T}}, M$. imitans $4229^{\mathrm{T}}, M$. indiense $3 \mathrm{~T}^{\mathrm{T}}, M$. iners $\mathrm{PG} 30^{\mathrm{T}}, M$. iowae $695^{\mathrm{T}}, M$. leocaptivus $3 \mathrm{~L} 2^{\mathrm{T}}, M$. leopharyngis $\mathrm{LL} 2^{\mathrm{T}}, M$. lipofaciens $\mathrm{R} 171^{\mathrm{T}}, M$. lipophilum $\mathrm{MaBy}^{\mathrm{T}}, M$. maculosum $\mathrm{PG} 15^{\mathrm{T}}, M$. meleagridis $17529^{\mathrm{T}}, M$. moatsii $\mathrm{MK} 405^{\mathrm{T}}, M$. mobile $163 \mathrm{~K}^{\mathrm{T}}$, $M$. molare $\mathrm{H} 542^{\mathrm{T}}, M$. muris $\mathrm{RIII} 4^{\mathrm{T}}, M$. mustelae $\mathrm{MX} 9^{\mathrm{T}}, M$. mycoides subsp. mycoides $\mathrm{B} 3, M$. mycoides subsp. capri $\mathrm{PG}^{\mathrm{T}}, M$. neurolyticum Type $\mathrm{A}^{\mathrm{T}}, M$. opalescens $\mathrm{MH} 5408^{\mathrm{T}}, M$. orale $\mathrm{CH} 19299^{\mathrm{T}}, M$. ovipneumoniae $\mathrm{Y}^{2} 8^{\mathrm{T}}, M$. oxoniensis $128^{\mathrm{T}}, M$. penetrans GTU54 ${ }^{\mathrm{T}}, M$. phocacerebrale $1049^{\mathrm{T}}, M$. phocarhinis $852^{\mathrm{T}}, M$. phocidae $105^{\mathrm{T}}$, M. pirum $70-159^{\mathrm{T}}, M$. pneumoniae $\mathrm{FH}^{\mathrm{T}}, M$. primatum $\mathrm{HRC} 292^{\mathrm{T}}$, $M$. pullorum $\mathrm{CKK}^{\mathrm{T}}, M$. pulmonis $\mathrm{PG} 34^{\mathrm{T}}, M$. putrefaciens $\mathrm{KS}-1^{\mathrm{T}}, M$. salivarium $\mathrm{PG}^{2} 0^{\mathrm{T}}, M$. simbae $\mathrm{LX}^{\mathrm{T}}, M$. spermatophilum $\mathrm{AH} 159^{\mathrm{T}}, M$. spumans $\mathrm{PG} 13^{\mathrm{T}}, M$. sualvi Mayfield $\mathrm{B}^{\mathrm{T}}, M$. subdolum $\mathrm{TB}^{\mathrm{T}}, M$. synoviae $\mathrm{WVU} 1853^{\mathrm{T}}, M$. testudinis $01008^{\mathrm{T}}, M$. yeatsii $\mathrm{GIH}^{\mathrm{T}}, M$. verecundum $107^{\mathrm{T}}$, Mycobacterium sp. strain California calf (joint strain), Mycoplasma sp. strain B5P (bovine joint strain), Mycoplasma sp. strain M7806 (cat oropharynx strain), Mycoplasma sp. strain 3306 (ovine genital strain), Mycoplasma sp. strain HRC291 (primate throat strain), Mycoplasma sp. strain 3446 (bovine fetus strain), Mycoplasma sp. strain B689 (dog throat strain), Mycoplasma sp. strain GM257A (caprine ear strain), and Mycoplasma sp. strain Utah C (tortoise nasal strain). The $M$. agalactiae $\mathrm{PG}^{\mathrm{T}}, M$. anatis $1340^{\mathrm{T}}, M$. arginini $\mathrm{G} 230^{\mathrm{T}}, M$. arthritidis $\mathrm{PG}^{\mathrm{T}}, M$. bovigenitalium $\mathrm{PG} 11^{\mathrm{T}}, M$. bovirhinis $\mathrm{PG} 43^{\mathrm{T}}, M$. buccale $\mathrm{CH} 20247^{\mathrm{T}}, M$. canis $\mathrm{PG} 14^{\mathrm{T}}, M$. faucium $\mathrm{DC} 333^{\mathrm{T}}$,

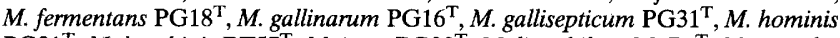
$\mathrm{PG} 21^{\mathrm{T}}, M$. hyorhinis BT5 $7^{\mathrm{T}}, M$. iners $\mathrm{PG} 30^{\mathrm{T}}, M$. lipophilum $\mathrm{MaBy}^{\mathrm{T}}, M$. maculosum $\mathrm{PG}^{\mathrm{T}}{ }^{\mathrm{T}}, M$. meleagridis $17529^{\mathrm{T}}, M$. neurolyticum Type $\mathrm{A}^{\mathrm{T}}, M$. orale $\mathrm{CH} 19299^{\mathrm{T}}$, M. pneumoniae $\mathrm{FH}^{\mathrm{T}}$, M. pulmonis $\mathrm{PG} 34^{\mathrm{T}}$, M. salivarium $\mathrm{PG} 20^{\mathrm{T}}$, and $M$. spumans $\mathrm{PG} 13^{\mathrm{T}}$ reagents were National Institutes of Health reference reagents; all other reagents were prepared by the Mycoplasma Section of the Laboratory of Molecular Microbiology at the National Institute of Allergy and Infectious Diseases. Agar colonies of strain $\mathrm{G} 145^{\mathrm{T}}$ were tested by both the disc growth inhibition technique (4) and the plate immunofluorescence procedure $(11,14)$, using antisera and fluorescein-conjugated antisera, respectively, to the 


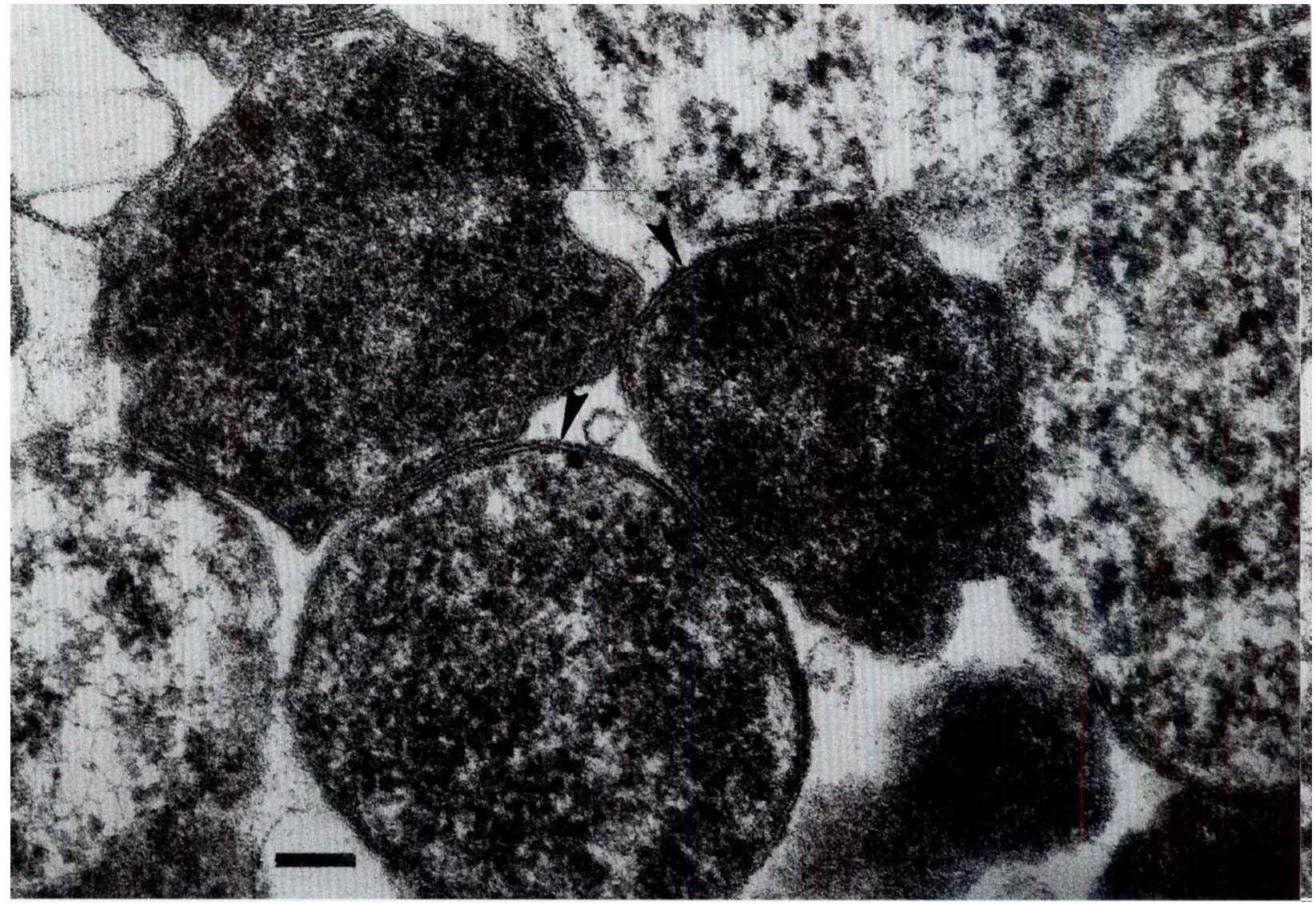

FIG. 1. Electron micrograph of a thin section of a strain $G 145^{\mathrm{T}}$ cell pellet, showing the cellular morphology and the three-layer cytoplasmic membrane (arrowheads). Magnification, $\times 100,000$. Bar $=100 \mathrm{~nm}$.

species listed above. One minor modification was made; strain $\mathrm{G} 145^{\mathrm{T}}$ agar colonies were examined only in an immunofluorescence test with conjugated antiserum to $M$. agalactiae $\mathrm{PG}^{\mathrm{T}}$, since the unconjugated antiserum to $M$. agalactiae exhibited low homologous potency in growth inhibition tests.

\section{RESULTS AND DISCUSSION}

Morphology and cultural properties. Liquid cultures of strain $\mathrm{G} 145^{\mathrm{T}}$ contained numerous pleomorphic, round or coccobacillary forms, as determined by dark-field microscopy. Preparations stained by the Gram technique contained gramnegative pleomorphic structures similar to those observed by dark-field microscopy. Electron microscopy of thin sections of logarithmic-phase cultures revealed predominately coccoid elements devoid of cell wall material. The coccoid cells varied in diameter from 300 to $600 \mathrm{~nm}$, and each cell was surrounded by a single cytoplasmic membrane (Fig. 1).

Colonies of strain $\mathrm{G} 145^{\mathrm{T}}$ on horse serum agar medium exhibited classic fried-egg morphology after 4 to 7 days of anaerobic incubation at $35^{\circ} \mathrm{C}$ (Fig. 2). The optimum temperature for growth ranged from 35 to $37^{\circ} \mathrm{C}$.

Reversion studies. Cultures of $\mathrm{G} 145^{\mathrm{T}}$ maintained in antibiotic-free liquid media for at least five consecutive passages exhibited growth characteristics similar to those of cultures grown in the presence of penicillin. There was no evidence of reversion to bacterial colonies when the strain was plated onto conventional bacteriological blood agar.

Filtration studies. Filtrates of liquid cultures of strain $\mathrm{G} 145^{\mathrm{T}}$ contained viable cells after passage through all of the membrane filters tested. The titer of the unfiltered control culture was $4.6 \times 10^{6} \mathrm{CFU} / \mathrm{ml}$. The titers of filtrates after passage through filters having pore sizes of $800,450,300$, and $220 \mathrm{~nm}$ were $3.89 \times 10^{6}, 1.76 \times 10^{5}, 8.9 \times 10^{4}$, and $4.1 \times 10^{4} \mathrm{CFU} / \mathrm{ml}$, respectively.

Biochemical and biological properties. Strain $\mathrm{G} 145^{\mathrm{T}}$ hydro-

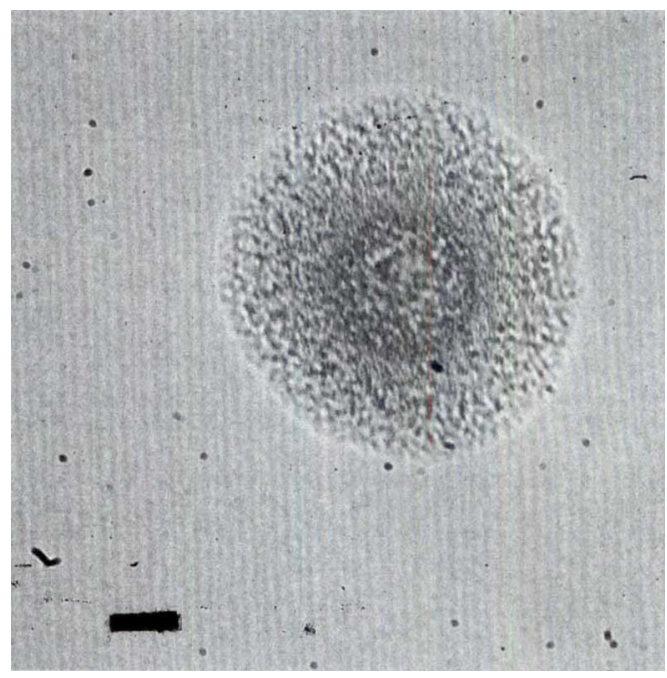

FIG. 2. Colony of strain $\mathrm{G} 145^{\mathrm{T}}$ on $20 \%$ horse serum agar after 3 days of anaerobic incubation at $37^{\circ} \mathrm{C}$. Bar $=100 \mu \mathrm{m}$. 
TABLE 1. Growth responses of strain $\mathrm{G} 145^{\mathrm{T}}$ to cholesterol

\begin{tabular}{|c|c|c|}
\hline $\begin{array}{l}\text { Supplement(s) added to } \\
\text { serum-free base medium }\end{array}$ & $\begin{array}{l}\text { Cholesterol } \\
\text { concn }(\mu \mathrm{g} / \mathrm{ml})\end{array}$ & $\begin{array}{l}\text { Amt of protein } \\
(\mathrm{mg} / \mathrm{ml})\end{array}$ \\
\hline Bovine serum fraction $(1 \%)$ & Control & 3.37 \\
\hline None & 0 & $\mathrm{IG}^{a}$ \\
\hline \multirow{5}{*}{$\begin{array}{l}\text { Albumin }(1 \%) \text {, Tween } 80(0.01 \%) \text {, } \\
\text { and palmitic acid }(10 \mu \mathrm{g} / \mathrm{ml})\end{array}$} & 0 & 0.72 \\
\hline & 1 & 1.13 \\
\hline & 5 & 1.83 \\
\hline & 10 & 3.56 \\
\hline & 20 & 3.86 \\
\hline
\end{tabular}

${ }^{a}$ IG, insufficient growth for protein measurement.

lyzed arginine and did not hydrolyze urea or ferment glucose. Colonies of strain $\mathrm{G} 145^{\mathrm{T}}$ failed to hemadsorb guinea pig erythrocytes. Additional biochemical and biological properties of the strain are summarized in the taxonomic description below.

Sterol requirement. The growth responses of strain $\mathrm{G} 145^{\mathrm{T}}$ to additions of cholesterol are shown in Table 1. Little growth was apparent in the base liquid medium alone or when the base medium was supplemented with albumin, Tween 80 , and palmitic acid. Growth increased as greater amounts (1 to 20 $\mathrm{g} / \mathrm{ml}$ ) of cholesterol were incorporated into the base medium.

Serologic tests. The results of growth inhibition and plate immunofluorescence tests, which were performed with antisera or conjugates prepared to the mycoplasmas listed above, indicated that strain G145 ${ }^{\mathrm{T}}$ was not related serologically to any of the previously described Mycoplasma species or to a collection of currently unnamed strains that belong in the genus.

The properties of strain $\mathrm{G} 145^{\mathrm{T}}$ described above fulfill the essential criteria (15) for placing species in the class Mollicutes; these criteria include absence of a cell wall, filterability, lack of reversion to walled bacteria when the organism is grown in antibiotic-free media, penicillin resistance, and production of typical colonial forms on agar. The morphology of G145 ${ }^{\mathrm{T}}$, the sterol requirement for growth, and an optimum temperature of more than $30^{\circ} \mathrm{C}$ place this strain in the order Mycoplasmatales and the family Mycoplasmataceae (21). The inability of strain G145 ${ }^{\mathrm{T}}$ to hydrolyze urea, in addition to the properties described above, mandates assignment of the strain to the genus Mycoplasma. Strain $\mathrm{G} 145^{\mathrm{T}}$ is serologically distinct from all previously described species in the genus Mycoplasma.

We propose the name Mycoplasma adleri for this strain, in recognition of the important contributions that Henry E. Adler made to our understanding of mycoplasmas of caprine and avian origin. The taxonomic description below summarizes the properties of the species.

Mycoplasma adleri sp. nov. Mycoplasma adleri (ad' ler.i. N.L. gen. n. adleri, of Adler, named for Henry Adler, a California veterinarian whose studies contributed much new information concerning the pathogenic role of caprine and avian mycoplasmas).

Cells are primarily coccoid and vary in diameter from 300 to $600 \mathrm{~nm}$. Cells lack cell walls and are nonmotile. The colonies have a typical fried-egg appearance on a variety of agar media when the organism is incubated in an anaerobic environment. Colonies do not hemadsorb guinea pig erythrocytes or produce film and spot reactions. Arginine is hydrolyzed. There is no reaction with urea or glucose. Phosphatase and serum lique- faction reactions are negative. Tetrazolium reduction is variable. The optimum growth temperature is 35 to $37^{\circ} \mathrm{C}$. The strain is chemoorganotrophic and dependent on cholesterol for growth. The guanine-plus-cytosine content of the DNA has been reported to be $29.6 \pm 1 \mathrm{~mol} \%$, as determined by the buoyant density method (16).

Strain $\mathrm{G} 145^{\mathrm{T}}$ is serologically distinct from other Mycoplasma species.

The habitat is unknown because only one strain has been isolated; this strain was isolated from a leg abscess of a goat. Pathogenicity is unknown.

The type strain is G145 (= ATCC 27948).

\section{ACKNOWLEDGMENT}

We thank Roger M. Cole for his efforts in the ultrastructural examination of strain $\mathrm{G} 145^{\mathrm{T}}$.

\section{REFERENCES}

1. Aluotto, B. B., R. G. Wittler, C. O. Williams, and J. E. Faber. 1970. Standardized bacteriologic techniques for the characterization of Mycoplasma species. Int. J. Syst. Bacteriol. 20:35-58.

2. Barile, M. F., R. A. Del Giudice, and J. G. Tully. 1972. Isolation and characterization of Mycoplasma conjunctivae sp. $\mathrm{n}$. from sheep and goats with keratoconjunctivitis. Infect. Immun. 5:70-76.

3. Bradbury, J. M. 1977. Rapid biochemical tests for characterization of Mycoplasmatales. J. Clin. Microbiol. 5:531-534.

4. Clyde, W. A., Jr. 1964. Mycoplasma species identification based upon growth inhibition by specific antisera. J. Immunol. 92:958-963.

5. Cole, R. M. 1983. Transmission electron microscopy: basic techniques. Methods Mycoplasmol. 1:43-50.

6. Cottew, G. S. 1974. The mycoplasmas of sheep and goats. Colloq. INSERM (Inst. Natl. Sante Rech. Med.) 33:357-382.

7. Cottew, G. S. 1979. Caprine-ovine mycoplasmas, p. 103-132. In J. G. Tully and R. F. Whitcomb (ed.), The mycoplasmas, vol. 2. Academic Press, Inc., New York.

8. Cottew, G. S. 1983. Recovery and identification of caprine and ovine mycoplasmas. Methods Mycoplasmol. 2:91-104.

9. Cunningham, S. 1978. NIAID catalog of research reagents. Department of Health, Education and Welfare publication (NIH) 78-899. National Institutes of Health, Bethesda, Md.

10. DaMassa, A. J., P. S. Wakenell, and D. L. Brooks. 1992. Mycoplasmas of goats and sheep. J. Vet. Diagn. Invest. 4:101-113.

11. Del Giudice, R. A., N. F. Robillard, and T. R. Carski. 1976. Immunofluorescence identification of mycoplasma on agar by use of incident illumination. J. Bacteriol. 93:1205-1209.

12. Edward, D. G. ff. 1947. A selective medium for pleuropneumonia-like organisms. J. Gen. Microbiol, 1:238-243.

13. Gardella, R. S., and R. A. Del Giudice. 1983. Hemagglutination, hemadsorption, and hemolysis. Methods Mycoplasmol. 1:379-384.

14. Gardella, R. S., R. A. Del Giudice, and J. G. Tully. 1983. Immunofluorescence. Methods Mycoplasmol. 1:431-439.

15. International Committee on Systematic Bacteriology Subcommittee on the Taxonomy of Mollicutes. 1979. Proposal of minimal standards for descriptions of new species of the class Mollicutes. Int. J. Syst. Bacteriol. 29:172-180.

16. Neimark, H. C. 1970. Division of mycoplasmas into subgroups. J. Gen. Microbiol. 63:249-263.

17. Razin, S., and J. G. Tully. 1970. Cholesterol requirement of mycoplasmas. J. Bacteriol. 107:306-310.

18. Tully, J. G. 1983. Cloning and filtration techniques for mycoplasmas. Methods Mycoplasmol. 1:173-177.

19. Tully, J. G. 1983. Tests for digitonin sensitivity and sterol requirement. Methods Mycoplasmol. 1:355-362.

20. Tully, J. G., M. F. Barile, D. G. ff Edward, T. S. Theodore, and H. Ernø. 1974. Characterization of some caprine mycoplasmas, with proposals for new species, Mycoplasma capricolum and Mycoplasma putrefaciens. J. Gen. Microbiol. 85:102-120.

21. Tully, J. G., J. M. Bové, F. Laigret, and R. F. Whitcomb. 1993. Revised taxonomy of the class Mollicutes: proposed elevation of a monophyletic cluster of arthropod-associated mollicutes to ordinal rank (Entomoplasmatales ord. nov.), with provision for familial rank to separate species with nonhelical morphology (Entomoplasmataceae fam. nov.) from helical species (Spiroplasmataceae), and emended descriptions of the order Mycoplasmatales, family Mycoplasmataceae. Int. J. Syst. Bacteriol. 43:378-385. 